\title{
JAN CHRISTIAAN SMUTS.
}

In die geskiedenis van Suid-Afrika was daar geen enkele leier oor whe se persoon soveel meningsverskil bestaan as wyle Generaal Smuts nie. Vereer deur sy partygenote in ons land en tallose bewonderaars dwarsdeur die wêreld, is hy nogtans deur die grootste deel van sy volk as leier verwerp en dikwels gehoon. Met sy verdwyning van die aardse toneel sal die tryd oor sy betekenis en rol in die geskiedenis ook nie ophou nie, en die penne van publisiste en historici sal nog lank na sy dood in beweging bly. Maar dat sy loopbaan allesins merkwaardig was en die moeite van noukeurige studie en analise loon, sal iedereen geredelik toegee. 
Hier het ons die geval van 'n eenvoudige Boerseun van die Boland wat staatsprokureur van president Kruger word, 'n republikeinse veggeneraal en bittereinder in die Tweede Vryheidsoorlog, wat eenmaal selfs deur sy Engelse teenstanders bestempel is as die onversoenlikste van die Boereleiers. Hier het ons 'n man wat in Mei 1902 op die vredeskongres van Vereeniging diep bewoë kon uitroep: „Ons buig voor Gods wil. Die toekoms is duister maar ons sal die moed, die hoop, die vertroue op God nie prysgee nie. Niemand sal my ooit oortuig dat die ongeëwenaarde opofteringe wat die Afrikaanse volk op die altaar van die vryheid gelê het, ydel en tevergeefs is. Die Vryheidsoorlog van Suid-Afrika is gestry, nie net vir die Boere nie, maar vir die ganse volk van Suid-Afrika. Die uitkoms van daardie stryd laat ons in Gods hand. Miskien is dit sy wil om die volk van Suid-Afrika deur neerlaag, deur vernedering, ja selfs deur die dal van die doodskaduwee te lei tot 'n betere toekoms in ' $n$ heldere dag." Dit is dieselfde man wat nog gedurende 1903 en 1904 in briewe aan President Kruger en Emily Hobhouse sy eie nood en dié van sy volk kon kla en nog geen lig vir die toekoms kon sien nie.

Daarna kom die ommekeer, want hy aanvaar die toekenning van selfbestuur aan Transvaal in 1906 met alles wat dit meebring: die finale verdwyning van die nasionale onafhanklikheid, die Britse vlag en onderdaanskap as 'n voldonge feit. Hy word 'n minister van die kroon saam met Genl. Botha, hy word een van die boumeesters van die Unie van Suid-Afrika, argitek en verdediger van die Britse Ryk, ontwerper van die Volkebond en die V.V.O. en totaal onverskillig wat betref die nasionale ontwikkeling van sy eie volk, so selfs dat hy uitgekryt word as die aartsimperialis van sy tyd. Hy word oorlaai met eerbewyse van die kant van Engelse universiteite en korporasies, en aan sy bors pryk militêre ordes en titels van die Ryk waaraan hy getrou bly dwarsdeur twee wêreldoorloë, maar wat hy tog per slot van rekening beskou as slegs 'n middel tot nog 'n groter doelwit in die ontplooiïng van die wêreld. En dwarsdeur alles is daar nog steeds 'n aansienlike deel van sy eie volk wat hom volg, nie as veldmaarskalk deur die grasie van 'n vreemde vors nie, maar as Boeregeneraal kragtens verdienstes wat behaal is in 'n oorlog teen daardie selfde ryk ' $n$ halwe eeu tevore. Vir hulle het hy die nimbus van vryheidsstryder nooit verloor nie.

Wat 'n teenstrydigheid lê opgesluit in sy lewensloop! Die vriend van vorste, vertroude raadsman in die kanselarye van die wêreld, bouer van die Britse Ryk, bekende wêreldfiguur, "staatsman, filosoof, wetenskaplike, en veldheer," wat 'n afstand skei hom nie van die staatsprokureur en guerillaleier van die Boere-Republiek nie! 
'n Noukeurige studie van sy lewensloop bewys egter dat Smuts merkwaardig konsekwent opgetree het. Reeds as jong man het hy steeds die grotere doelwit nagestreef van nasionale en politieke eenheid van die blanke ras in Suid-Afrika, soos hy duidelik laat blyk het in 'n openbare rede van 1895. Maar hy was ook steeds afkerig van gewelddadige metodes om daardie doel te bereik en daarom het hy in 1896 na die Jameson-inval sy rug op Cecil Rhodes gekeer en in diens van die SuidAfrikaanse Republiek onder president Kruger getree. Daarmee het hy die ideaal van politieke eenheid nie verwerp nie, maar hy wou dit nou bereik deur middel van die Republiek in plaas van deur die Kaapkolonie. Tien jaar later, na die mislukte vryheidsoorlog moes hy erken dat dit langs daardie weg nie moontlik is nie, en van nou af streef hy na unifikasie onder die Britse vlag, wat dan ook in 1910 tot stand kom.

Hier het Smuts 'n lewensfout begaan deur staatkundige unifikasie as identies met nasionale eenheid te beskou en die begripsverwarring sou hom nooit weer verlaat nie. Hy het vergeet dat die opbou van 'n nuwe nasie uit Engels- en Afrikaanssprekende dele die uitkoms is van 'n langsame historiese proses van samegroeiing en nooit 'n kunsmatige skepping van 'n leier of politieke party kan wees nie. Omdat hy te haastig was, het hy diegene wat die aparte identiteit van die Boerenasie bepleit het, cenkanttoe gestoot en van enge separatisme verwyt. Hy kon eenvoudig nie begryp dat die Afrikaner by 'n eenheidstrewe heelhartig slegs sy gewig kan inwerp as hy eers versekerd is van volkome politieke en kulturele gelykstelling. Juis daarom het genl. Hertzog se program, wat op die werklikheid gebaseer was, veel meer tot die volk gespreek.

Die vervreemding van sy volk is ook vergroot deurdat Smuts in sy holistiese strewe hom gedurig met lof uitgelaat het oor die Britse Ryk en sy plek in die groot wêreld daarbuite. Vanaf sy Olimpiese hoogtes het hy die wêreld van ver aanskou terwyl die siel van sy eie volk vir hom terra incognita gebly het.

Was hy dan 'n „verraaier," soos sy politieke vyande hom in SuidAfrika soms genoem het? Geensins. Smuts was wel geen Boer nie, maar nog minder Engelsman, eerder wêreldburger wat ver oor die grense van Suid-Afrika en Engeland gekyk het. Vir hom was steeds die geheel die eindpunt, terwyl die deel slegs middel daartoe was, 'n klein rat in 'n ingewikkelde masjien. As staatsman en politikus in Suid-Afrika was hy per slot van rekening ' $n$ mislukking omdat hy sy landsbeleid al te seer in diens gestel het van 'n onbereikbare en onmoontlike ideaal wat 'n uitvloeisel was van sy holistiese lewens- en wêreldbeskouing.

Daarby het sy veelvuldige openbare uitlatings aangaande Engeland en die Britse Ryk en Suid-Afrika se plek in die skema, te dikwels die 
indruk geskep van verloëning van sy eie volk en verheerliking van alles wat Engels is. Hierdie indruk was oppervlakkig, want dis volkome duidelik dat Smuts bloedweining aan enge Engelse kulturele invloede onderhewig was. Veral in sy jonger jare was dit eerder Kant en Hegel, Schiller en Goethe wat tot hom gespreek het. Nou is dit eenmaal so dat die Afrikaner nooit 'n filosoof as leier sal aanvaar nie, veral nie iemand met ideale soos lugspiëelinge wat buite die onmiddellike politieke horison lê nie.

Smuts se mensheidsideaal mag in die antieke gepas het, maar nie in die deur nasionalistiese strewe vermoeide en verdeelde wêreld van vandag nie. Ook daarom kon sy volk hom nie verstaan nie en daarom is hy as nasionale leier verwerp. Dit was die tragedie van sy lewe, want daardie verwerping het hom by wyse van reaksie steeds verder na die ander uiterste gedryf. Ten slotte was hy gelukkiger agter 'n professorale kateder in Oxford of Cambridge as in die raadsale van sy eie land.

Nou moet ons oordeel, maar alles in ag geneem wie kan die lewensraaisel van 'n ander oplos? In die lewe is dit nou eenmaal so dat die mens sy loopbaan nooit beplan en volgens ' $n$ logiese ontwikkelingswet uitleef nie. Die een stap lei na die ânder, en die eindpunt is vir ons sterfelinge nie sigbaar nie. Soos ' $n$ arend opvlieg en hoër styg, maak dit altyd groter sirkels totdat die berge en dale van die aarde ver benede 'n effe vlak vertoon en alle onderskeidende kenmerke verlore raak. Slegs weiniges is dit gegee om tot sulke hoogtes op te styg, maar dan moet hulle ook bereid wees om die verwyt te verduur dat hulle alle belangstelling vir die besondere verloor deurdat die blik te seer gevestig is op die horison waar lug en land aaneensmelt, waar lande en volkere nie meer bestaan nie, maar slegs die eindelose en kleurlose. So kon Smuts se koers nie ons s'n wees nie, maar tog het dit hom, miskien sonder dat hy dit oorspronklik so gewil het, in 'n vaste baan na 'n vreemde bestemming gelei.

Smuts, soos ook ander manne in die openbare lewe, het in sy loopbaan 'n onsigbaar geweefde band agter hom aangetrek. Dit het deurmekaar gestrengel, geleidelik 'n bont tapyt gevorm en die legende van sy lewe geweef. Self kon hy dit moontlik nie verklaar nie, seker is dit dat hy dit vooraf nie heeltemal kon beplan nie. Vir ons. wat nog so naby staan, is dit nog moeiliker om die geheim van sy lewenspatroon te deurgrond. Wat ons intussen van die persoon van Jan Christiaan Smuts mag dink, is dit baie seker dat hy ' $n$ unicke en groot gees was en dat sy figuur 'n skaduwee sal werp tot lank na ons tyd nog.

Potchefstroom.

D. W. KRÜGER. 